Jurnal Keperawatan Silampari

Volume 4, Nomor 1, Desember 2020

e-ISSN: 2581-1975

p-ISSN: 2597-7482

DOI: https://doi.org/10.31539/jks.v4i1.1430

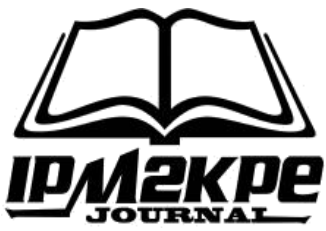

\title{
TERAPI KOMPLEMENTER UNTUK PENATALAKSANAAN KECEMASAN ATAU DEPRESI PADA LANSIA YANG TINGGAL DI KOMUNITAS
}

\author{
Arjuna $^{1}$, Etty Rekawati ${ }^{2}$ \\ Universitas Indonesia ${ }^{1,2}$ \\ arjunaazazi@gmail.com ${ }^{1}$
}

\begin{abstract}
ABSTRAK
Penelitian ini bertujuan untuk mengetahui terapi komplementer yang dapat diterapkan pada penatalaksanaan kecemasan dan depresi pada orang tua di komunitas. Metode dalam pencarian artikel melalui database dalam bahasa inggris : EBSCO host, Scopus, Pro Quest, Wiley Online Library, Sage Publications, Science direct, dan Springer Link pada 10 tahun terakhir. Hasil pencarian didapat 282 artikel dan 6 artikel yang teridentifikasi yang memenuhi kriteria inklusi. Analis systematic review menggunakan diagram PRISMA. Ada enam terapi komplementer yang digunakan yaitu aromaterapi, reiki, terapi tawa, akupresur, agama, aromaterapi, musik, dan reiki. Simpulan, Semua terapi komplementer ini efektif dalam pengelolaan kecemasan atau depresi. terapi komplementer yang disarankan dalam penatalaksanaan kecemasan yaitu aromaterapi sedangkan depresi yaitu terapi agama.
\end{abstract}

Kata Kunci: Depresi, Kecemasan, Orang Tua, Terapi komplementer

\section{ABSTRACT}

This study aims to determine complementary therapies that can be applied to managing anxiety and depression in the elderly in the community. Methods for searching articles through English databases: EBSCO host, Scopus, Pro-Quest, Wiley Online Library, Sage Publications, Science direct, and Springer Link in the last ten years. The search results obtained 282 articles, and six reports identified that met the inclusion criteria. Systematic review analysts use the PRISMA diagram. There are six complementary therapies used: aromatherapy, reiki, laughter therapy, acupressure, religion, aromatherapy, music, and reiki. In conclusion, all of these complementary therapies are effective in the management of anxiety or depression. The complementary treatment suggested in the direction of pressure is aromatherapy, while depression is religious therapy.

Keywords: Depression, Anxiety, Parents, Complementary Therapy

\section{PENDAHULUAN}

Menurut World Health Organization (WHO) peningkatan populasi lanjut usia (lansia) di dunia sangat pesat (WHO, 2015). Pada tahun 2018, pertama kalinya dalam sejarah lansia berusia 65 tahun atau lebih di seluruh dunia melebihi jumlah anak di bawah usia lima tahun (United Nations, 2019). Diperkirakan pada tahun 2050 jumlahnya akan berlipat ganda dengan proyeksi hampir 2,1 miliar (United Nations, 2017). 
Bertambahnya jumlah lansia akan berefek pada bertambahnya gangguan kesehatan mental yang dialami lansia. Adapun kesehatan mental yang sering ditemui pada lansia yaitu kecemasan dan depresi (Cheruvu \& Chiyaka, 2019; Nies \& McEwen, 2019). Hasil penelitian yang dilakukan Albert et, al (2019) pada lansia dikomunitas yang mengalami perawatan dirumah ditemukan ada $25,7 \%$ lansia yang mengalami gejala depresi dan kecemasan. Dan penelitian yang dilakukan di Odhisa India pada 268 responden lansia, $42,6 \%$ menunjukkan gejala kecemasan ringan; sedangkan 38,1\% memiliki tingkat kecemasan sedang, dan seperlima $(18,4 \%)$ memiliki kecemasan berat (Nayak et al., 2018). Sedangkan penelitian yang dilakukan di Turki 32,8\% lansia mengalami depresi (Özyurt et al., 2018). Artinya kecemasan dan depresi yang terjadi pada lansia prevalensinya relatif tinggi.

Kecemasan yang terjadi pada lansia disebabkan oleh beberapa factor, diantaranya keuangan, masalah kesehatan, kurangnya interaksi sosial akibat kematian dan relokasi pada lansia (Nies \& McEwen, 2019). Kesepian juga merupakan faktor resiko terjadinya kecemasan pada lansia (Domènech-Abella et al., 2019). Menurut (Nayak et al., 2018) faktor ekonomi berperan penting penyebab kecemasan pada lansia, disusul mengunyah tembakau atau merokok (Nayak et al., 2018). Sedangkan faktor resiko gangguan depresi pada lansia cenderung pada jenis kelamin perempuan, berpendidikan rendah, hidup sendirian, bergantung ekonomi pada orang lain, dan memiliki minimal satu penyakit kronis (Özyurt et al., 2018). Hal ini sering ditemukan pada kehidupan nyata lansia yang berada di komunitas.

Jika tidak diatasi segera, kecemasan yang terjadi terus menerus pada lansia dapat menjadi gangguan yang serius. Secara sosial gangguan kecemasan pada lansia dapat menimbulkan isolasi sosial, penolakan jika diberi bantuan, meminta sesuatu yang berlebihan dan meningkatnya angka bunuh diri (MHA-NYC, 2018). ${ }^{D}$ epresi yang tidak diatasi dapat meningkatkan ketergantungan sosial, pemanfaatan pelayanan kesehatan yang tinggi, resiko rawat inap, sehingga menurunkan kualitas hidup pada lansia (Pramesona \& Taneepanichskul, 2018). Sehingga penatalaksanaan kecemasan dan depresi pada lansia perlu dilakukan agar kesehatan pada lansia tetap optimal.

Ada beberapa penatalaksanaan pada kecemasan dan depresi yang dapat dilakukan diantaranya menggunakan psikofarmaka dan non-psikofarmaka. Hal ini dapat disebabkan karena biaya yang lebih terjangkau dibandingkan perawatan medis, dan efek samping dari perawatan medis yang dirasa berat pada pasien (Saritaş et al., 2018). Sehingga terapi komplementer dapat menjadi alternatif dalam penatalaksanaan kecemasan dan depresi pada lansia.

Beberapa penelitian dari jenis terapi komplementer efektif dalam penatalaksanaan kecemasan dan depresi pada lansia yaitu aromaterapi akupresur dan terapi agama (Sok, 2016; Pramesona \& Taneepanichskul, 2018). Penelitian yang telah dilakukan sudah terbukti dalam penatalaksanaan kecemasan dan depresi pada lansia yang dilakukan sesuai kriteria inklusi masing-masing penelitian dengan adanya perbandingan kelompok control. Artinya efektifitas dari intervensi komplementer tersebut sudah dibuktikan kebenarannya sehingga hal ini bukan menjadi fokus dalam systematic review ini.

Diluar dari efektifitas penerapan terapi komplementer di komunitas, sejauh ini, hasil penelitian sebelumnya sudah dapat diajdikan acuan. Metodelogi ini memaparkan bukti ilmiah yang paling kuat dalam penatalaksanaan kecemasan dan depresi. Oleh karena itu systematic review ini bertujuan untuk mengetahui terapi komplementer yang dapat diterapkan pada penatalaksanaan kecemasan atau depresi lansia yang berada di komunitas. 


\section{METODE PENELITIAN}

\section{Strategi Penelusuran Literature}

Metode penelusuran literature ini dilakukan secara sistematis, Awalnya dilakukan pencarian artikel melalui online. Pencarian database yang digunakan yaitu EBSCO host, Scopus, Pro Quest, Wiley Online, Sage Publications, and Science direct. Pencarian artikel dilakukan dalam rentang waktu 10 tahun terakhir yaitu 2009-2019. Penelusuran artikel mengunakan pedoman Prisma Statement, dengan kata kunci pencarian: "Complementary Therapy" AND "anxiety" OR "depression" AND "elderly" AND "community" Adapun kriteria inklusi yang harus terpenuhi dari artikel yang ditemukan adalah : (1) artikel harus berbahasa inggris, (2) metode penelitian quasy experiment and randomized controlled trials, (3) subjek penelitian adalah lansia di komunitas yang memiliki kecemasan dan depresi atau salahsatunya, (4) menyebutkan hasil dari kecemasan dan depresi atau salahsatunya. Kriteria ekslusi : (1) kecemasan dan depresi disertai demensia, penyakit jantung, diabetes mellitus dan penyakit berat lainnya (2) hanya satu kata kunci yang muncul dalam pencarian artikel.

\section{Prosedur dan Analisis Artikel}

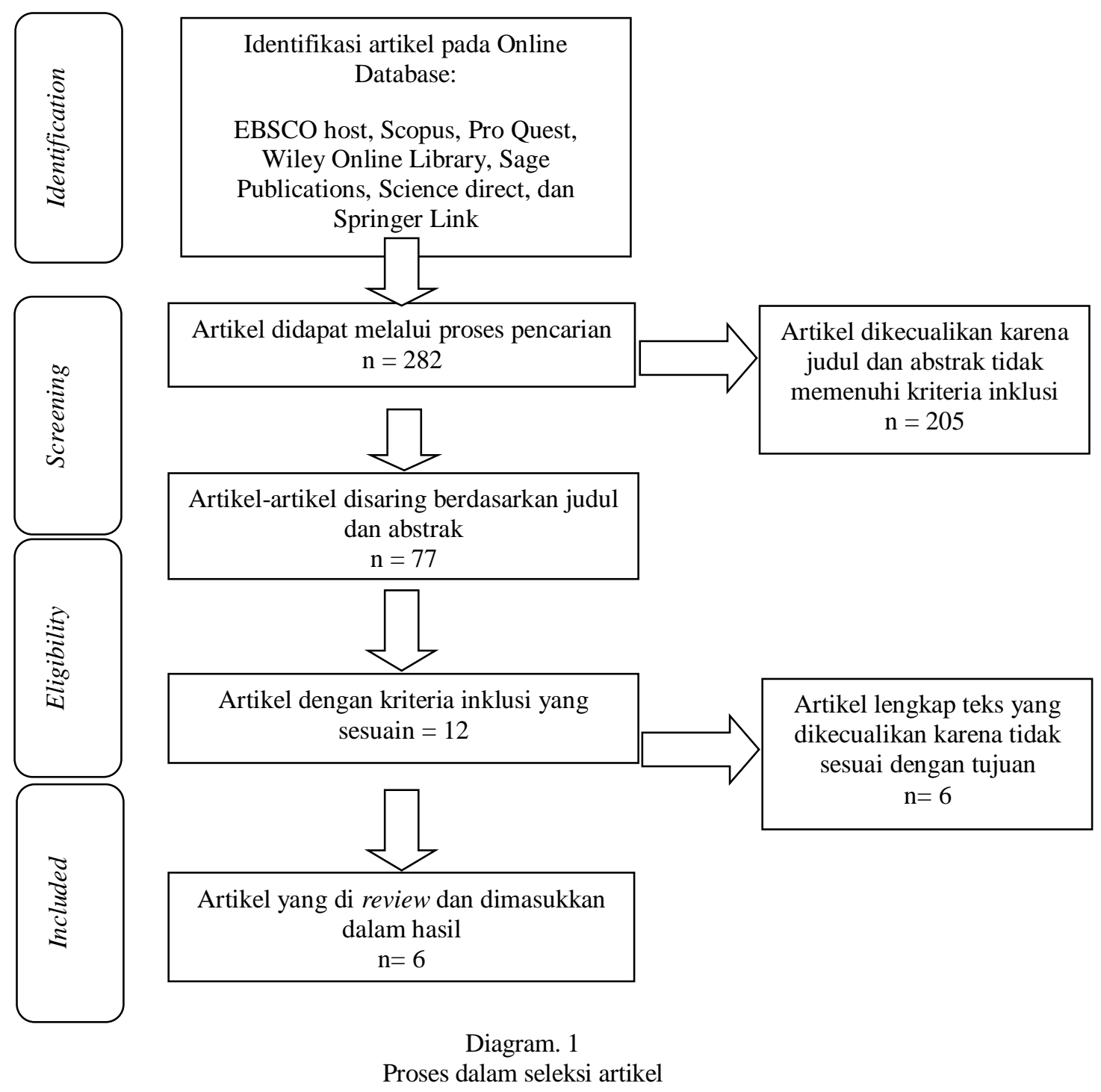


Adapun prosedur sistematik review ini mengunakan pedoman prisma statment dengan proses sebagai berikut: (1) pencarian artikel melalui enam database dengan kata kunci. (2) proses screening dilakukan dengan filter yang ada pada pilihan database serta menggunakan kriteri inklusi dan ekslusi yang telah ditetapkan, (3) menganalisis artikel ke dalam table secara manual (4) dilanjutkan dengan analisis artikel menggunakan tools Joanna Briggs Institute 2017.

\section{HASIL PENELITIAN}

Hasil penelusuran dari tujuh database diperoleh 282 artikel, kemudian diperkecil dengan screening dari pilihan database menjadi 77 artikel, dilanjutkan seleksi secara manual seleksi judul, abstrak artikel, dan kesesuaian latar belakang, tujuan, motode, dan hasilnya menjadi 12. Enam artikel yang dianalisis mengunakan tabel, selanjutnya dilakukan penilaian dengan tools Joanna Briggs Institute 2017. Dari enam artikel tersebut 5 artikel dengan metode quasi-exsperimental dan 1 artikel metode a randomised controlled trial. Hasil dari semua terapi komplementer yang dipilih efektif dalam penatalaksanaan kecemasan atau depresi pada lansia di komunitas. Analisis artikelnya dibawah ini :

Tabel. 1

Karakteristik dan Systematic Review Terapi Komplementer untuk Penatalaksanaan Kecemasan atau Depresi $(n=6)$

\begin{tabular}{|c|c|c|c|c|}
\hline No & $\begin{array}{l}\text { Pengarang, Judul, } \\
\text { Jenis Literatur }\end{array}$ & Tahun & Tujuan & Hasil Temuan \\
\hline 1 & $\begin{array}{l}\text { Tang, } \\
\text { Aromatherapy: } \\
\text { Does It Help to } \\
\text { Relieve Pain, } \\
\text { Depression, } \\
\text { Anxiety, and } \\
\text { Stress in } \\
\text { Community- } \\
\text { Dwelling Older } \\
\text { Persons? quasi- } \\
\text { experimental } \\
\text { pretest dan } \\
\text { posttest dengan } \\
\text { control group }\end{array}$ & 2014 & $\begin{array}{l}\text { Pengetahuan efektif } \\
\text { aromaterapi untuk } \\
\text { mengelola Depresi, } \\
\text { Kecemasan, dan Stres } \\
\text { pada orang tua dengan } \\
\text { nyeri }\end{array}$ & $\begin{array}{l}\text { Aromaterapi } \\
\text { efektif untuk } \\
\text { mengurangi depresi, } \\
\text { kecemasan pada } \\
\text { orang tua yang } \\
\text { tinggal di komunitas }\end{array}$ \\
\hline 2 & $\begin{array}{l}\text { Nancy, Effects of } \\
\text { Reiki on Anxiety, } \\
\text { Depression, Pain, } \\
\text { and Physiological } \\
\text { Factors in } \\
\text { Community- } \\
\text { Dwelling Older } \\
\text { Adults, An } \\
\text { experimental } \\
\text { randomly, design } \\
\text { with } \\
\text { control group } \\
\text { (2010) }\end{array}$ & 2010 & $\begin{array}{l}\text { Tujuan dari penelitian } \\
\text { ini adalah untuk } \\
\text { mengevaluasi efek } \\
\text { dari Reiki sebagai } \\
\text { terapi komplementer } \\
\text { untuk mengobati pada } \\
\text { orang tua yang tinggal } \\
\text { di komunitas yang } \\
\text { mengalami rasa sakit, } \\
\text { depresi, atau } \\
\text { kecemasan. }\end{array}$ & $\begin{array}{l}\text { Reiki dapat } \\
\text { digunakan sebagai } \\
\text { salahsatu intervensi } \\
\text { untuk kecemasan dan } \\
\text { depresi pada orang } \\
\text { tua di komunitas }\end{array}$ \\
\hline
\end{tabular}




\begin{tabular}{|c|c|c|c|c|}
\hline 3 & $\begin{array}{l}\text { Moon, Effect of } \\
\text { Quran recitation } \\
\text { on the level of } \\
\text { anxiety in } \\
\text { athletics, a } \\
\text { randomised } \\
\text { controlled } \\
\text { trial (2011) }\end{array}$ & 2011 & $\begin{array}{l}\text { Untuk mengetahui } \\
\text { efek musik pada } \\
\text { tingkat depresi pada } \\
\text { orang dewasa yang } \\
\text { lebih tua }\end{array}$ & $\begin{array}{l}\text { Mendengarkan musik } \\
\text { dapat membantu } \\
\text { mengurangi tingkat } \\
\text { depresi pada Lansia } \\
\text { yang Tinggal di } \\
\text { Komunitas }\end{array}$ \\
\hline 4 & $\begin{array}{l}\text { Ko, Effects of } \\
\text { laughter therapy } \\
\text { on depression, } \\
\text { cognition and } \\
\text { sleep among the } \\
\text { community- } \\
\text { dwelling elderly, } \\
\text { quasi- } \\
\text { experimental, } \\
\text { pretest-posttest } \\
\text { control group } \\
\text { design (2011) }\end{array}$ & 2011 & $\begin{array}{l}\text { Untuk mengetahui } \\
\text { efek terapi tawa pada } \\
\text { depresi, fungsi } \\
\text { kognitif, } \\
\text { kualitas hidup, dan } \\
\text { tidur untuk orang tua } \\
\text { dalam suatu } \\
\text { komunitas }\end{array}$ & $\begin{array}{l}\text { Efek terapi tawa pada } \\
\text { depresi (skor GDS } \\
\text { rata-rata) menurun } \\
\text { secara signifikan } \\
\text { untuk lansia }\end{array}$ \\
\hline 5 & $\begin{array}{l}\text { Sok, Effects of } \\
\text { Meridian } \\
\text { Acupressure in } \\
\text { Joktaeyang } \\
\text { Bangkwang } \\
\text { Kyeong on the } \\
\text { Physical Health } \\
\text { State, Depression, } \\
\text { and Life } \\
\text { Satisfaction of } \\
\text { Korean Older } \\
\text { Adult Women } \\
\text { Living Alone, A } \\
\text { quasi- } \\
\text { experimental, } \\
\text { pretest-posttest } \\
\text { control group } \\
\text { design (2016) }\end{array}$ & 2016 & $\begin{array}{l}\text { Tujuan dari penelitian } \\
\text { ini adalah untuk } \\
\text { mengetahui pengaruh } \\
\text { akupresur meridian } \\
\text { pada kesehatan fisik, } \\
\text { kepuasan hidup, dan } \\
\text { depresi wanita dewasa } \\
\text { Korea yang masih } \\
\text { tinggal sendirian. }\end{array}$ & $\begin{array}{l}\text { Efek akupresur } \\
\text { menurunkan depresi } \\
\text { lebih banyak pada } \\
\text { kelompok } \\
\text { eksperimen daripada } \\
\text { pada kelompok } \\
\text { kontrol. }\end{array}$ \\
\hline 6 & $\begin{array}{l}\text { Pramesona, The } \\
\text { effect of religious } \\
\text { intervention on } \\
\text { depressive } \\
\text { symptoms and } \\
\text { quality of life } \\
\text { among Indonesian } \\
\text { elderly in nursing } \\
\text { homes : A quasi- } \\
\text { experimental } \\
\text { study, A quasi- } \\
\text { experimental } \\
\text { study (2019) }\end{array}$ & 2019 & $\begin{array}{l}\text { Studi ini membahas } \\
\text { intervensi agama pada } \\
\text { depresi dan quality of } \\
\text { life (QOL) pada } \\
\text { orang tua }\end{array}$ & $\begin{array}{l}\text { Intervensi berbasis } \\
\text { agama memiliki efek } \\
\text { yang signifikan } \\
\text { dalam } \\
\text { menghilangkan gejala } \\
\text { depresi }\end{array}$ \\
\hline
\end{tabular}




\section{Terapi Komplementer \\ Aromaterapi}

Dalam penelitian ini, bergamot essential oils and lavender hydrolats dilarutkan terlebih dahulu. Kemudian semprotan aromatik digunakan secara eksternal, melalui inhalasi oleh responden selama terapi. Hasil penelitian ini menyebutkan aromaterapi dapat menurunkan kecemasan dan depresi pada lansia. Suasana hati mereka membaik setelah menghirup minyak esensial dan semprotan aromatik, sehingga terjadi penurunan skor depresi dan kecemasan.

\section{Reiki}

Dalam penelitian ini efek positif dari reiki dapat menurunkan kecemasan dan depresi pada lansia di komunitas dengan skor GDS-15 ( $p<0,001)$ dan HAM-A $(p<0,001)$ pada kelompok intervensi dibandingkan dengan kelompok control. Hasil wawancara dengan responden setelah treatment reiki mereka merasa lebih santai, merasa ketenangan pikiran, gembira dan tidur lebih berkualitas.

\section{Musik}

Dalam penelitian ini terbukti music dapat menurunkan depresi pada lansia di komunitas $(\mathrm{F}=7,05, \mathrm{p}$ value $=0,006)$. Mekanisme dari music dalam penatalaksanaan depresi yaitu dengan mengaktifkan respons psikofisiologis seseorang dengan bekerja pada sistem limbik.

\section{Terapi Tertawa}

Terapi tawa memberikan informasi tentang cara dalam pembuatan humor. Terapi tawa efektif dalam mengatasi depresi lansai yang ada di komunitas. Meskipun terapi tertawa memiliki efek positif pada depresi dan tidur, tetapi pada penelitian ini belum jelas apakah penatalaksanaan pada depresi menyebabkan perbaikan kualitas tidur atau terapi tawa secara mandiri yang berefek positif pada depresi dan tidur pada lansia.

\section{Akupresur}

Pada penelitian ini, titik akupresur yang pada jari tangan participants. Hasilnya, ada pengaruh yang signifikan $(\mathrm{t}=3,241, \mathrm{p}<0,001)$ pada lansia yang mengalami depresi setelah diberikan akupresur.

\section{Agama}

Pada penelitian ini kelompok eksperimen diberikan intervensi mendengarkan murottal Al-Qur'an dan khotbah. Sedangkan kelompok control perawatan seperti biasanya. Pada kedua kelompok, ada penurunan skor depresi yang signifikan secara statistik setelah intervensi 12 minggu $(P=0,001)$. Namun, kelompok intervensi agama (mendengarkan murottal Al-Qur'an dan khotbah) menunjukkan penurunan yang lebih besar dalam gejala depresi dibandingkan dengan kelompok kontrol. Intervensi mendengarkan Al-Qur'an dan kotbah berfungsi sebagai pedoman untuk hidup sebagai Muslim agar hatinya tenang.

\section{PEMBAHASAN}

Ada beberapa penatalaksanaan pada kecemasan dan depresi yang dapat dilakukan diantaranya menggunakan psikofarmaka dan non-psikofarmaka. Hal ini dapat disebabkan karena biaya yang lebih terjangkau dibandingkan perawatan medis, dan efek samping dari 
perawatan medis yang dirasa berat pada pasien (Saritaş et al., 2018). Sehingga terapi komplementer dapat menjadi alternatif dalam penatalaksanaan kecemasan dan depresi pada lansia.

Beberapa penelitian dari jenis terapi komplementer efektif dalam penatalaksanaan kecemasan dan depresi pada lansia yaitu aromaterapi akupresur dan terapi agama (Sok, 2016; Pramesona \& Taneepanichskul, 2018).

Pada intervensi aromaterapi efektif dalam menurunkan kecemasan depresi pada lansai. Penelitian yang membandingkan efektifitas minyak lavender dan minyak pohon teh ditemukan perbedaan yang signifikan hanya pada minyak lavender dalam menurunkan kecemasan (p <0,001) (Özkaraman et al., 2018). Penelitian lain menyebutkan minyak lavender juga efektif dalam menurunkan tingkat kecemasan pada seseorang (Reis \& Jones, 2018). Pada penelitian lain menyebutkan aromaterapi menggunakan air mawar juga efektif mengurangi kecemasan pada pasien hemodialisis. Inhalasi air mawar dapat meningkatkan kondisi emosional dan spiritual pasien sehingga berefek pada penurunan kecemasan (Barati et al., 2016).

Kecemasan yang terjadi pada lansia disebabkan oleh beberapa factor, diantaranya keuangan, masalah kesehatan, kurangnya interaksi sosial akibat kematian dan relokasi pada lansia. Kesepian juga merupakan faktor resiko terjadinya kecemasan pada lansia (Domènech-Abella et al., 2019). Menurut (Nayak et al., 2018) faktor ekonomi berperan penting penyebab kecemasan pada lansia, disusul mengunyah tembakau atau merokok (Nayak et al., 2018). Sedangkan faktor resiko gangguan depresi pada lansia cenderung pada jenis kelamin perempuan, berpendidikan rendah, hidup sendirian, bergantung ekonomi pada orang lain, dan memiliki minimal satu penyakit kronis (Özyurt et al., 2018). Hal ini sering ditemukan pada kehidupan nyata lansia yang berada di komunitas.

Jika tidak diatasi segera, kecemasan yang terjadi terus menerus pada lansia dapat menjadi gangguan yang serius. Secara sosial gangguan kecemasan pada lansia dapat menimbulkan isolasi sosial, penolakan jika diberi bantuan, meminta sesuatu yang berlebihan dan meningkatnya angka bunuh diri (MHA-NYC, 2018).

Studi reiki dalam penatalaksanaan kecemasan dan depresi pada lansia efektif dalam menurunkan tingkat keceamsan dan depresi. Penelitian yang dilakukan pada pasien cancer yang melakukan kemoterapi, bahwa reiki dapat menurunkan rata-rata kecemasan dari 6,77 menjadi 2,28 ( $\mathrm{P}<0,000001)$ dengan satu kali sampai empat kali treatment (Birocco et al., 2012) Kecemasan pada lansia di nursing home mengalami penurunana secara signifikan pada minggu 4, 8 dan 12 setelah diberi treatment reiki (Erdogan \& Cinar, 2016). Artinya reiki dapat diterapkan di diberbagai setting dalam menurunkan kecemasan pada lansia termasuk lansia yang di komunitas.

Music membuat efek pada psikologisnya sehingga mempengaruhi suasana hati. musik yang disukai dapat membuat seseorang rileks, sehingga berefek positif pada orang yang mengalami depresi. Terapi musik lebih efektif dalam mengatasi kecemasan dan depresi pada usia yang lebih muda dibandingkan orang yang lebih tua (Chen et al., 2016).

Pada terapi tawa dan menurunkan depresi pada lansia. Penelitian menggunakan pengukuran Turkish Death Anxiety Scale (TDAS) didapatkan bahwa terapi tawa berpengaruh terhadap depresi pada kelompok intervensi, tetapi tidak berpengaruh signifikan antara kelompok intervensi dan control (Alıcı et al., 2018). Hasil Meta-analisis dari sepuluh study mengatakan terapi tawa memiliki efek yang positif pada orang yang mengalami depresi (Zhao et al., 2019).

Pada penganut agama islam, terapi agam yang efektif dalam penatalaksanaan depresi adalah hal-hal yang berkaitan dengan ritual pendekatan pada Tuhan seperti 
mendengar Murottal dan kitab seperti penelitian ini. Al-Qur'an surah Ar-Ra'du ayat 28 yang maknanya "orang-orang yang beriman dan hati mereka menjadi tentram dengan mengingati Allah. Ingatlah, hanya dengan mengingat Allah-lah hati menjadi tenteram". Artinya ketika mengingat Tuhan, hati seseorang akan terasa tenang.

Hasil studi di Iran menyebutkan agama (membaca Al-Qur'an dan Sholawat pada Rosulullah Sollahu 'alaihi wasalam) memiliki peran yang efektif menurunkan kecemasan pada orangtua dengan anaknya dirawat di rumah sakit saat kecemasannya muncul (Naimi et al., 2019). Studi lain menyebutkan, orang yang taat menjalankan perintah agama yang dianutnya kemungkinan lebih kecil mengalami depresi yang menyebabkan kematian (Vanderweele et al., 2017).

Pembahasan systematic review, semua intervensi dikatakan kuat dalam penatalaksanaan kecemasan atau depresi pada lansia di komunitas. Bukti yang disajikan dua intervensi (aromaterapi dan reiki) pada kecemasan dan enam intervensi (music, aromatherapy, akupresur, reiki, laughter dan religion) efektif dalam penatalaksanaan depresi lansia di komunitas. Walaupun efektif, pada setiap intervensi yang diterapkan dalam penelitian memiliki kelebihan dan kelemahan masing-masing. Semua sampelnya kecil dan yang paling kecil pada intervensi reiki hanya 15 sampel untuk kelompok perlakuan dan 12 sampel pada kelompok control.

Semua intervensi efektif dalam menurunkan depresi pada lansia di komunitas. Pada intervensi musik, tidak ada sampel yang droop out. Ada sebagian responden tidak nyaman penggunaan earphone pemutaran MP3 musik, sehingga ini dapat mempengaruhi hasil karena mereka tidak merasa nyaman. selain itu adanya budaya Tiongkok yang sangat menghormati terhadap professional layanan kesehatan sehingga bisa menimbulkan efek hawthorne pada hasil penelitian. Intervensi tawa menggunakan sampel yang cukup besar di awal baik pada kelompok intervensi maupun control yang masing-masing kelompok 100 sampel. Setelah berjalannya waktu penelitian hanya 48 pada kelompok intervensi dan 60 pada kelompok control yang bisa diambil datanya. Artinya adanya kekurangan dari peneliti dalam mempertahankan sampel dalam penelitian sampai proses penelitian selesai.

Intervensi religion diberikan selama 12 minggu tanpa ada yang droop out, penggunaan kuesioner yang valid, pengacakan surah dan ayat Al-Qur'an meminimalkan bias dan pemilihan penceramah yang berasal dari perawat yang berlisensi. Disamping kelebihan tersebut, dalam penelitian ini peneliti tidak mengetahui apakan penurunan depresi pada lansia efek dari mendengarkan Al-Qur'an atau ceramah yang diberikan (Pramesona \& Taneepanichskul, 2018). Walaupun demikian, Al-Qur'an dan ceramah sama-sama intervensi religion yang bisa diterapkan orang yang menyakininya untuk menurunkan depresi. Intervensi ini dapat dijadikan pertimbangkan oleh perawat komunitas dalam penatalaksanaa depresi di lapangan.

\section{SIMPULAN}

Berdasarkan artikel ini, semua terapi komplementer dapat diterapkan dalam penatalaksanaan kecemasan atau depresi pada lansia di komunitas. Adapun terapi komplementer yang disarankan penulis dalam penatalaksanaan keceamsan pada lansai yang ada di komunitas yaitu aromaterapi sedangkan pada depresi yaitu terapi agama.

\section{SARAN}

Disarankan pada perawat, terutama perawat komunitas dapat memberikan intervensi keperawatan yaitu terapi komplementer dalam penatalaksanaan kecemasan atau depresi pada lansia yang tinggal di komunitas. Pada penerapan terapi komplementer, 
seorang perawat komunitas harus memantau klien sebelum, proses, dan setelah proses intervensi. Hal ini dilakukan untuk memaksimalkan efek terapeutik pada klien.

\section{DAFTAR PUSTAKA}

Albert, S. M., King, J., Anderson, S., Dew, M. A., Zhang, J., Stahl, S. T., \& Reynolds, C. F. (2019). Depression Agency-Based Collaborative: Effect of Problem-Solving Therapy on Risk of Common Mental Disorders in Older Adults with Home Care Needs. American Journal of Geriatric Psychiatry, 27(6), 619-624. https://doi.org/10.1016/j.jagp.2019.01.002

Alıc1, N. K., Zorba, P., Oya, B., \& Emiroğlu, N. (2018). The Preliminary Effects of Laughter Therapy on Loneliness and Death Anxiety among Older Adults Living in Nursing Homes: A Nonrandomised Pilot study. International Journal of Older People Nursing, 13(4), 1-9. https://doi.org/10.1111/opn.12206

Barati, F., Nasiri, A., Akbari, N., \& Sharifzadeh, G. (2016). The Effect of Aromatherapy on Anxiety in Patients. Nephro-Urology Monthly, 8(5). https://doi.org/10.5812/numonthly.38347

Chen, X., Hannibal, N., \& Gold, C. (2016). Randomized Trial of Group Music Therapy With Chinese Prisoners: Impact on Anxiety, Depression, and Self-Esteem. International Journal of Offender Therapy and Comparative Criminology, 60(9), 1060-1081. https://doi.org/10.1177/0306624X15572795

Cheruvu, V. K., \& Chiyaka, E. T. (2019). Prevalence of Depressive Symptoms among Older Adults Who Reported Medical Cost as a Barrier to Seeking Health Care: Findings from a Nationally Representative Sample. BMC Geriatrics, 19(1), 192. https://doi.org/10.1186/s12877-019-1203-2

Domènech-Abella, J., Mundó, J., Haro, J. M., \& Rubio-Valera, M. (2019). Anxiety, Depression, Loneliness and Social Network in the Elderly: Longitudinal Associations from the Irish Longitudinal Study on Ageing (TILDA). Journal of Affective Disorders, 246, 82-88. https://doi.org/10.1016/j.jad.2018.12.043

Erdogan, Z., \& Cinar, S. (2016). The effect of Reiki on depression in elderly people living in nursing home. Indian Journal of Traditional Knowledge 15(1), 35-40. http://nopr.niscair.res.in/handle/123456789/33556

Naimi, E., Babuei, A., Moslemirad, M., Rezaei, K., \& Eilami, O. (2019). The Effect of Spirituality Intervention on the Anxiety Parents of Hospitalized Newborns in a Neonatal. Journal of Religion and Health. https://doi.org/10.1007/s10943-01800753-y

Nayak, S., Mohapatra, M. K., \& Panda, B. (2018). Prevalence of and Factors Contributing to Anxiety, Depression and Cognitive Disorders among Urban Elderly in Odisha A Study Through the Health Systems' Lens. Archives of Gerontology and Geriatrics, 80(267), 38-45. https://doi.org/10.1016/j.archger.2018.09.008

Özkaraman, A., Dügüm, Ö., Yılmaz, H. Ö., \& Yeşilbalkan, Ö. U. (2018). The Effect of Lavender on Anxiety and Sleep Quality in Patients Treated with Chemotherapy. Clinical Journal of Oncology Nursing 22(2), 203-211. DOI: 10.1188/18.CJON.203-210

Özyurt, B. C., Elbi, H., \& Serifhan, M. (2018). Prevalence of Depression in the Elderly Population of Manisa and Related Risk Factors. Turk Geriatri Dergisi, 21(4), 579587. https://doi.org/10.31086/tjgeri.2018.65 
Pramesona, B. A., \& Taneepanichskul, S. (2018). The Effect of Religious Intervention on Depressive Symptoms and Quality of Life Among Indonesian Elderly in Nursing Homes: A Quasi-Experimental Study. Clinical Interventions in Aging, 13, 473484.DOI: $10.2147 /$ CIA.S162946

Reis, D., \& Jones, T. (2018). Aromatherapy Using Essential Oils as a Supportive Therapy. Clinical Journal of Oncology Nursing, 21(1), 19-22. DOI: 10.1188/17.CJON.16-19

Saritaş, S., Kavak, F., \& Savaş, B. (2018). The effect of lavender oil on anxiety levels of patients before laparoscopic cholecystectomy. Complementary Therapies in Clinical Practice, 32, 51-54. https://doi.org/10.1016/j.ctcp.2018.05.003

Sok, S. R. (2016). Effects of Meridian Acupressure in Joktaeyang Bangkwang Kyeong on the Physical Health State, Depression, and Life Satisfaction of Korean Older Adult Women Living Alone. Journal of Gerontological Nursing, 42(2), 28-35. DOI: 10.3928/00989134-20151218-01

United Nations. (2017). World Population Ageing. The United Nations. https://www.un.org/en/development/desa/population/theme/ageing/WPA2017.asp

United Nations. (2019). World Population Prospects 2019. In Department of Economic and Social Affairs. World Population Prospects 2019. Retrieved from http://www.ncbi.nlm.nih.gov/pubmed/12283219

Vanderweele, T. J., Yu, J., Cozier, Y. C., Wise, L., Argentieri, M. A., Rosenberg, L., \& Shields, A. E. (2017). Original Contribution Attendance at Religious Services, Prayer , Religious Coping, and Religious / Spiritual Identity as Predictors of AllCause Mortality in the Black Women's Health Study. Am J Epidemiol, 185(7), 515-522. https://doi.org/10.1093/aje/kww179

Zhao, J., Yin, H., Zhang, G., Li, G., Shang, B., Wang, C., \& Chen, L. (2019). A Meta Analysis of Randomized Controlled Trials of Laughter and Humour Interventions on Depression, Anxiety and Sleep Quality in Adults. Journal of Advanced Nursing, 75(11), 2435-2448. DOI: https://doi.org/10.1111/jan.14000 